\title{
Local Populations - Sources of Germplasm in Maize Breeding
}

\author{
Carmen-Daniela ROTAR ${ }^{1,2}$, Ioan HAȘ1,2, Ana COPÂNDEAN11, Voichița HAȘ1 \\ ${ }_{1}^{1}$ Agricultural Research and Development Station-Turda, 27 Agriculturii Street, 401100, Turda, \\ România. \\ 2 Facuty of Agriculture, University of Agricultural Sciences and Veterinary Medicine \\ Cluj-Napoca, 3-5 Mănăștur Street, 400372, Cluj-Napoca, România. \\ *corresponding author: ioanhas@yahoo.com
}

Bulletin USAMV series Agriculture 72(1)/ 2015

Print ISSN 1843-5246; Electronic ISSN 1843-5386

DOI. $10.15835 /$ buasvmcn-agr: 11048

\begin{abstract}
The spread limitation of local populations forced to organize a national program for the collection, study and preservation of indigenous germplasm due to outstanding value starting material of populations and varieties that are the result of long natural selection. Collection of local populations of maize, maintaining the existing genetic resources collections resource assessment through qualitative descriptions of phenotypic expression, also quantitative descriptors assessing whether variability in populations collected from ARDS Turda.
\end{abstract}

Keywords: local populations, germplasm, genetic variability, sources of genes.

\section{INTRODUCTION}

Since the species Zea mays were used in a very small scale in national research projects maize germplasm has become a crucial objective for breeders. Germplasm is representative of local populations and unimproved varieties, synthetic and composite populations, inbred lines and hybrids (Murariu et al., 2012).

Population growth registered in the last decades has attracted more and more attention to the importance of biodiversity, genetic erosion and avoid irrecoverable losses.

Biodiversity conservation has become an important goal for most europeans since the last 50 years there has been a significant loss of biodiversity (HAS et al., 2009).

Restriction of areas with local populations and the introduction of advanced hybrid culture caused contamination of local populations (introgression). Currently, populations are grown mainly in households in hilly and pre-mountain areas.
Limiting the area of distribution of local populations forced to organize a national program for the collection, study and preservation of indigenous germplasm. This was required because of the special value as starting material in breeding (Roman et al., 1973; Haş et al., 2012), populations and varieties that are the result of long natural selection (Moşneagă, Velican and Priadcencu, 1957).

Genetic resources represented by local populations of maize from different areas, are important resources of useful genes for improving the species. The exploitation of these resources is possible through studies and complex measures that may lead to the preservation of biodiversity and increase its efficiency. In Romania, the collection and preservation of plant genetic material turned to genetic conservation of plant resources. They are valuable for breeders if they meet two conditions: genetic variability and their performance. 
As main objectives of the laboratory were gathering maize breeding local populations indigenous to maintain existing genetic resources collections by reproducing and storing them "in situ" (in the SCDA Turda) (Has, et al., 2006), evaluation of the descriptors phenotypic expression of qualitative, quantitative descriptors and assessment of the existence of variability within populations collected from ARDS Turda.

In addition to collection of populations actions at ARDS Turda, collection of local populations has been completed with some donations made by Geoagiu

Research

Station, Research Station

Suceava, Cluj-Napoca Veterinary Medicine and Veterinary Medicine of Banat, but also with projects like CEEX and AGRAL. Total population number was obtained through donations from 228 local populations from different areas of Romania.

\section{MATERIALS AND METHODS}

Local populations of maize were analyzed from different areas of Romania, where each population bears the imprint of the environment in which it formad and were subjected to empirical selection made by growers, each in its own way.

We have studied a total of 60 local populations and evaluated a number of 14 phenotypic traits:

- the vegetative characteristics

- the plant height, ear height of the insert, the total number of leaves / plant, number of leaves on top ear, the number of branches in the panicles;

- cob characters: cob length, number of rows / cob, number of kernels / row, color rachis;

- grain characters: grain type, grain color, grain content in proteins, oil and starches.

$$
\text { Coeficinet variability }(s \%)=\frac{\text { standard deviation }}{\text { mean }} \times \mathbf{1 0 0}=\%
$$

The statistical analysis of the results were performed by means of a suitable mathematical model, widely used, namely the calculation of the coefficient of variation (CV $\%)$.

To interpret the values of $s \%$ agreed following assessment scale variability (after Ceapoiu, 1968), when:

- $\mathrm{s} \%<10$ - low variability and very low;

- $10 \%<\mathrm{s} \%<20 \%$ - middle variability;

- $20 \%<s \%<30 \%$ - high variability;

- $\mathrm{s} \%>30 \%$ - very high variability of the measurements

\section{RESULTS AND DISCUSSIONS}

Vegetative characters

For the measurement of the local population of maize plants in terms of height (Table 1 ) has a middle variation ( $\mathrm{cv} \%=15.8)$, the larger height of the plant is $283 \mathrm{~cm}$ and the smallest height is $138 \mathrm{~cm}$.

From Table 2, making calculation of the coefficient of variation can be seen that the main cob insertion height, has a higher amplitude values between 42 and $132 \mathrm{~cm}$, the difference between them is $90 \mathrm{~cm}$, we can observe the highest coefficient of variation $28.8 \%$ of all the characters analyzed.

According to Figure 1, we see that the most local populations have the insertion height around $79.3 \mathrm{~cm}$ : 12 of the 60 populations analyzed have a height of insertion between 67-79 $\mathrm{cm}$ followed by 11 populations with values ranging from 80 to 92 $\mathrm{cm}$.

Of the 60 populations analyzed in terms of number of branches in the panicles , 20 of them have between 20 and 25 branches, values close to the average of 22.4 ramifications coefficient of variability is medium 17.7 per cent.

In addition to the three characters discussed above, the total number of leaves / plant and number of leaves above the ear, the coefficient of variability is very low $<10$ per cent. 
Tab. 1. Plant height $(\mathrm{cm})$

\begin{tabular}{lcc}
\hline & & Plant height $(\mathrm{cm})$ \\
\hline Number of cases & 60 \\
Mean & & 216.2 \\
Standard deviation & & 34.3 \\
Error & & 4.46 \\
The confidence level & Minimum & 8.9 \\
Amplitude variation & Maximum & 138 \\
& Range & 283 \\
Coefficient of variation $(\mathrm{cv} \%)$ & & 145 \\
\hline
\end{tabular}

Tab. 2. Cob insertion height $(\mathrm{cm})$

\begin{tabular}{llc}
\hline & & Cob insertion height $(\mathrm{cm})$ \\
\hline Number of cases & & 60 \\
Mean & & 79.3 \\
Standard deviation & & 22.86 \\
Error & & 2.97 \\
The confidence level & Minimum & 5.95 \\
Amplitud variation & Maximum & 42 \\
& Range & 132 \\
& Coefficient of variation & $(\mathrm{cv} \%)$ \\
\hline
\end{tabular}

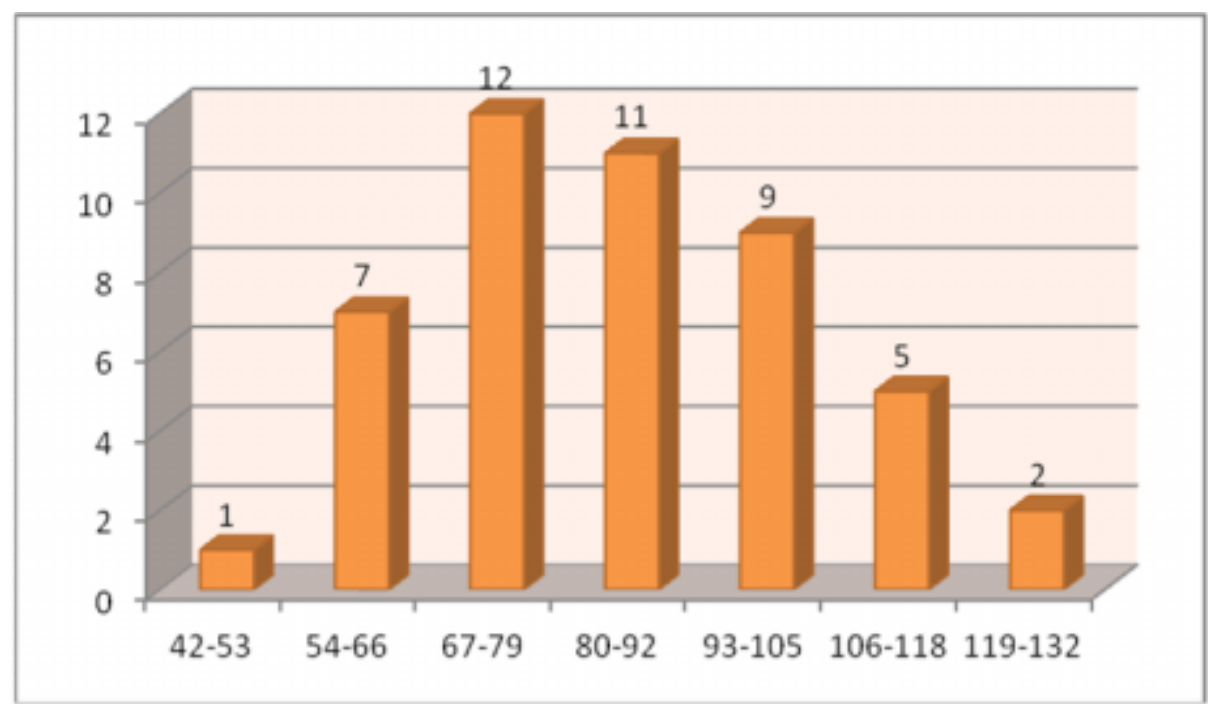

Fig. 1. Cob insertion height $(\mathrm{cm})$

Cob characters

From a total 60 population cob length is represented by an average of $17.7 \mathrm{~cm}$ (Table 4 ). The maximum length of the cob is $20-21$ $\mathrm{cm}$ at 19 population, followed by 18 populations with the cob length of 18 to 19 $\mathrm{cm}$, and the minimum value was at 2 populations with $10-12 \mathrm{~cm}$. Coefficient of variability of 15.6 per cent at cob length is middle. 
Tab .3. Number of branches in the panicle

\begin{tabular}{lcc}
\hline & & Number of branches in the panicle \\
\hline Number of cases & & 60 \\
Mean & & 22.4 \\
Standard deviation & & 3.9 \\
Error & 0.5 \\
The confidence level & Minimum & 1.03 \\
Amplitud variation & Maximum & 11 \\
& Range & 33 \\
& Coefficient of variation & (cv \% ) \\
\hline
\end{tabular}

Tab. 4. Cob length (cm)

\begin{tabular}{lcc}
\hline & & Cob length $(\mathrm{cm})$ \\
\hline Number of cases & & 60 \\
Mean & & 17.7 \\
Standard deviation & & 2.77 \\
Error & & 0.36 \\
The confidence level & Minimum & 0.72 \\
Amplitud variation & Maximum & 10 \\
& Range & 24 \\
& Coefficient of variation & (cv \%) \\
\hline
\end{tabular}

Tab. 5. Number of rows/ cob

Number of cases
Mean
Standard deviation
Error
Confidence level
Amplitud variation
Maximum
Range
Coefficient of variation (cv \% )
Coefficient of variability for the number of
rows / cob is 16.45 per cent (Table 5). 27
populations have the highest rows/ cob with
14 rows/ cob, followed by 14 populations with
12 rows / cob. The amplitude of variation for
number of grains / row is minimum 21 and
maximum 48 grains, and most populations,
with between $38-41$ grain / row. A statistical
analysis of the 60 populations (Table 6)
showed a middle coefficient of variation of
16.53 per cent.

Number of cases

Error

Confidence level

Amplitud variation

Maximm

Range
Grain type at the most populations is endured, followed by dentiform $\mathrm{x}$ endured, majority of populations have the color of kernel dark yellow, followed by normal yellow. Rachis color is white and red in most cases, but there are populations that have pink rachis.

The protein content is between 9.9 - 15.2 per cent, oil content has values between 3.9 6 per cent, and starch content between 60.1 71.6 per cent. 
Tab. 6. Number of grains/ row

\begin{tabular}{llc}
\hline & & Number of grains / row \\
\hline Number of cases & & 60 \\
Mean & & 34.1 \\
Standard deviation & 5.64 \\
Error & & 0.73 \\
Confidence level & Minimum & 1.47 \\
Amplitud variation & Maximum & 21 \\
& Range & 48 \\
Coefficient of variation (cv \% ) & 27 \\
\hline
\end{tabular}

\section{CONCLUSIONS}

As a result of the evaluation and analysis of the 60 local populations of maize, regarding 14 phenotypic characters, both in terms of growth and the characteristics of the ear, showed that there is a medium variation for the majority of characters, since the coefficient of variation (s\%) is between $10 \%<s \%<20 \%$.

The highest coefficient of variation $(\mathrm{s} \%)$ is meet at the cob insertion height of $28.8 \%$, being considered as a high coefficient.

From the results it appears that the analysis of descriptors that characterize the architecture of plants and ears there is enough variability to use some local populations of maize in breeding program, as starting material sources or improve traits.

This paper was published under the frame of European Social Fund, Human Resources Development Operational Programme 20072013, project no. POSDRU/159/1.5/S/132765.

\section{REFERENCES}

1. Căbulea I (1975). Germoplasma locală de porumb din Transilvania și utilizarea ei în lucrările de cercetare. In „Probleme de genetică teoretică și aplicată”, Vol. VII nr.1.
2. Căbulea I, Roman L, Tătaru V, Grecu C (1975). Germoplasma locală de porumb din Transilvania şi utilizarea ei în lucrările de ameliorare. În „Probleme de genetică teoretică și aplicată" vol. VII (1): 57-90.

3. Căbulea I (1987). Unele aspecte ale orientării lucrărilor de ameliorare a porumbului. Contribuţii ale cercetării ştiinţifice la dezvoltarea agriculturii, vol. Omagial (19571987): 169- 188

4. Ilicevici S (1994). Posibilities and limits of local germplasm utilization for releasing superior maize hybrids. Romanian Agricultural Research 2: 1-5.

5. Murariu M (2012). Conservarea si utilizarea germoplasmei locale de porumb din România. Editura PIM, Iași.

6. Roman L, Tătaru V, Grecu C (1973). Îmbunătătirea valorii biologice a provenienţelor locale de porumb prin crearea de populaţii sintetice. Contribuţii ale cercetării științifice la dezvoltarea agriculturii: 179-193.

7. Sarca T (2004). Ameliorarea porumbului. În , Porumbul - Studiu Monografic" vol. I. Editura Academiei Române, Bucureşti;

8. Sarca T (2004). Ameliorarea porumbului. Cap. 10: 363-450. Porumbul - Studiu monografic, vol. I Biologia porumbului. Editura Academiei Române, ISBN 973-27-1056-X/973-27-10551.

9. Has V, Has I, Pamfil D, Copândean A, Câmpean S (2009). Evaluatin of "Turda" maize germoplasm for phenotypic variability in grain chemical compozition". Maydica 54: 313-320. 